\title{
O Despertar do Laboratorio Chimico da Escola Politécnica
}

\author{
Graça Santa-Bárbara Ramallo
}

O Museu de Ciência da Universidade de Lishoa está instalado num edifício histórico da cidade.

No século XVH, nesse mesmo lugar fora construído o noviciado da Cotovia cm terrenos doados à Companhia de Jesus por Fernāo Telles de Menezes, ex governador da Índia e do Algarve, scndo Ballasar Alvares o autor da obra, cm 1603.

Un sécula depois, expulsos us jesuitas do país, o Marquês de Pombal utiliza o edíficio para a instalação do Real Colégio dos Nobres, após adaptação da estrutura existente, por Carlos Maruel, eri meados de 1700. Dessa época resta ainda hoje o Picadciro, classiticado pelo Instituto Português do Património Arquitectónico, em 1978. como Imóvel de Interesse Públi$\mathrm{co}$.

A revolução liberal trouxe a demecratizaçāo to ensino c o "źnico inslituto de insı ruçao superior nascido à sombra da libcruade" - nas palavras de Alexandre Herculano - a Escola Politécnica de Lisboa. instituída em 1837.

A libcralização na Escola Politécnica, não prescindia do rigor, da acıualização a par do ensino europeu e procurava a excelência. Assim, substituindo a Iéórica pela observação e pela expcrimentação. foram criados estabelecinentos de apoio ao ensjo experimental: um Jardim Botânico, um Observatório Astronóitrica, um Gabinete de Física, um Gabincte de Histónia Natural e um Laboratório Químico.

O laboratorio chimico da escola [Politécntica] é o mais vasto e a mesmo tempo mais grandioso que todos os laboraworios da Europa. em que estrdei, ot os que visitei.

Con csta avaliaçāo iniciava, em 1877, a protessor Agostirıho Vicente Lourenço o seu Rclatưrio rcferente a esse ano lectivo. Lourenço trabalhara no laboratório de Wurtz, no de Liebig c no de Bunscn, na Alemanha, c cum Holfmann em Londres, antes da sua entrada na Escula Politécnica como professor do Química Orgânica.

Onze anos mais tarde, José Júlio Bettencourt Rodrigues, professor de Química Mineral, consegue do governo a autorizaçăo e as verbas necessánias para instalar no Laboratorio o equipamento e as estruturas que possibilitam o ensino experimental da Química. Em I 890, o Laboratorio possui iluminaçào eléctrica, canalizaçōes de água, instalaçōes de gấs e vaņor nas suas I l bancadas e nas 4 hottes, câmara escura para revelaçōes de espectrografia e fotografia, armártos replctos de material laboratonial. biblioteca própria e está pronto a receber us alunos inscritos na primeiro curso prático de Química da Escola Poliıécnica.

August von Hoffmann. discípulo de Liebig c criador dos laboratórios universitánios de Bona e Berlim foi enta convidato a visitar e dar o seu parecer sobre a obra de J. J. B. Rodrigues. Em Janeiro de 1891, a revista "O Occidente" publica a carta que Tloffmann dírigiu a José Júlia Rodrigues, após a visita e na qual se refere ao Laboratorio comn "um cstabclecimento científico de primeira ordem, do qual qualquer país 1eria o direito de se orgulhar", cujas salas de trabathos e audicório dispôem de uma protusão de ar c de luz raramentc euconırados, associando a elegância e a urilidade cono nenhum outro que conhecera.

Hoje, passados 1 I0 anos, o Laboratorio Chimico ć ainda raro. provavelmene único, a sua elegância mantém-se inalterável e o pás deve poder orgulhar-sc dc possuir o testemunho da excelência que atingiน o ensino e a investigação quínicos cm finais do século passado.

Porém, para quc continue a ser ı̉ı til, agora na preservaçāo e divulgação da cultura cicnlífica, é necessário recuperá-lo do desgaste do tempo e do uso c adaptá-lo às exigências museológicas de um espaço abcrto ao público. onde este palrimonio cienúfico portuutếs é exibido, explicado e preservado para o tuisiro.

O projecto de arquitctura nāo irá alıerar, nem a nivel da estrutura, nem do equipamento, o que de original restou até ans nossos dias. Apcnas scrá reposto aquilo que foi alterado ou deteriorado nos últimos cem anos. As paredes retomarāo o marmoreado ainda visivel sob as várias camadas de tinta, as bancadas scrảo cunsolidadas, os candeeiros da época colocados nos seus lygares de origem.

Tambén o projecto museológico asscgura a conservaçāo do ambiente originai na sua essência: grande parte da colecção de Química que pertenceu ao Laboratorio da $6^{\mathrm{a}}$ cadeira. Quinica Mineral conscrvada alé agora nas reservas do Museu de Ciência, voltará aos seus lugares de outrora, nas suas caixas c estojos guarhados nos grandes armários envidraçados. us pianos de reagentes sobre as bancadas, de modo a que os futuros visitantes pussam sentir o ambiente vivido no Laboratorio Chimico no século XTX. Mas năo só através do olhar: pelas suas próprias mäos e de um nodo participativo, utilizando réplicas e devidamontc acompanhacos por demonstradores qualiticados, puderäo tamhém tomar contacto com as grandes questōes que enfrentava a Química oitncentista.

É esse u projecto que o Museu de Ciência da Universidade de Lisboa pretende realizar, assim que lhe forem disponibilizados os recursos financeiros para o pôr en execução. 